ROCZNIK ADMINISTRACJI PUBLICZNEJ 2017 (3)

ARTYKUŁY Nauka administracji / Administrative science

DOI 10.4467/24497800RAP.17.012.7063

http://www.ejournals.eu/RAP/

ISSN 2449-7800 (online), ISSN 2449-7797 (druk), s. 182-204

MaLwina KostrzeWSKA-OBertanieC'

\title{
Wizerunek publiczny Urzędu Miasta Krakowa
}

\section{Wstęp}

„Służba mieszkańcom dla wspólnego dobra miasta podstawowym celem pracy urzędników”2 - słowa te przedstawiają misję realizowaną przez Urząd Miasta Krakowa.

Wizerunek publiczny przedsiębiorstw ma duży wpływ na różne dziedziny ich działalności. Jednak public relations zyskuje coraz większe znaczenie również $\mathrm{w}$ dziedzinie administracji publicznej. Pozornie urzędy nie sprzedają produktu, nie muszą utrzymywać się z zysków na rynku ani z nikim nie konkurują. Nic bardziej mylnego. To właśnie jednostki organizacyjne samorządu terytorialnego konkurują między sobą o większą ilość mieszkańców, inwestycje przedsiębiorców oraz dotacje z Unii Europejskiej. W większości gmin powstały osobne działy marketingu bądź angażowane są zewnętrzne podmioty, którym powierza się ocieplenie wizerunku regionu i zachęcenie potencjalnych inwestorów.

Każda instytucja podlega ocenie opinii publicznej, niezależnie, czy jest to prywatne przedsiębiorstwo czy organizacja publiczna.

$\mathrm{W}$ dosłownym tłumaczeniu $\mathrm{z}$ języka angielskiego public relations (PR) to relacje, stosunki publiczne. Znane są ludzkości od bardzo dawna - poczynając od rzymskiego Forum, poprzez średniowieczne domy kupieckie, aż do czasów najnowszych. Nie ma jednej właściwej definicji PR, istnieje ich około dwóch tysięcy.

Obecnie krajem, gdzie public relations jest najbardziej rozwinięte, są Stany Zjednoczone. Prekursorem amerykańskiego PR był Edward L. Bernays. Wykorzystywał on psychologię i współpracę z politykami, aby przekonać społeczeństwo, że amerykańska armia jest potęgą na świecie i każdy Amerykanin powinien być z niej dumny. Bernays stworzył pierwszy w świecie

1 Malwina Kostrzewska-Obertaniec, doktorantka, Instytut Politologii, Uniwersytet Pedagogiczny im. KEN w Krakowie.

2 Dane za strony internetowej: https://www.bip.krakow.pl/?mmi=9716 (dostęp: 15.05.2016). 
wydział uniwersytecki zajmujący się badaniem PR. Drugą, również ważną postacią amerykańskiej historii wizerunku publicznego był I. Lee, który jako pracownik podupadającej fabryki Rockefellerów przywrócił dawny blask przedsiębiorstwu.

Za najbardziej uniwersalną i łączącą wiele aspektów definicji PR uważa się definicję podaną przez S. Blacka. Stwierdził on, że „Public relations to sztuka i nauka osiągania harmonii $z$ otoczeniem poprzez wzajemne porozumienie oparte na prawdziwej i pełnej informacji”'. Moim zdaniem najbardziej trafna jest jednak definicja sformułowana przez założycieli firmy Burston-Masteller: public relations ,to umiejętność przekazanie właściwym osobom właściwej informacji we właściwym momencie dla wywołania pożądanego efektu"4. Wszystkie definicje mają wspólne aspekty. Pierwszym $\mathrm{z}$ nich jest wskazanie, że chodzi o planowe i perswazyjne komunikowanie się. Ponadto zawsze podkreśla się, że PR polega na wzmacnianiu sympatii i eliminowaniu antypatii oraz ustaleniu kierunków i sposobów działania.

Public relations jest działaniem realizowanym $\mathrm{w}$ różnego typu organizacjach: prywatnych przedsiębiorstwach, instytucjach kulturalnych, organizacjach sportowych, non profit, organizacjach wojskowych i samorządowych. Zakłada nie tylko przynoszenie zysków przedsiębiorstwu, lecz przede wszystkim ma zapewnić popyt w długim okresie, budować stabilną markę różnego rodzaju przedsiębiorstw oraz ich dobry wizerunek wśród pracowników oraz klientów. W wielu przedsiębiorstwach, którym zależy na dobrym postrzeganiu przez klientów i otoczenie, funkcjonują osobne działy zajmujące się wizerunkiem przedsiębiorstwa. PR powinien spełniać przede wszystkim funkcje:

- kontaktowe, czyli ma zapewnić dobrą komunikację między przedsiębiorstwem a szeroko pojętym otoczeniem,

- perswazyjne wobec środowisk pośredniczących w procesie informowania, czyli ma wywierać wpływ na sposób przekazywania przez media informacji o danym przedsiębiorstwie,

- budowania przyzwolenia i zaufania dla działań, które są przedmiotem oddziaływania,

- dbania o wizerunek przedsiębiorcy w taki sposób, aby był właściwy $\mathrm{z}$ uwagi na oferowane przez niego produkty,

- motywowania personelu na każdym szczeblu do jak najlepszego reprezentowania przedsiębiorstwa,

- dbania o dobre relacje wśród pracowników i członków organizacji,

- pomagania przy problemach związanych z pracą,

3 S. Black, Public relations, Warszawa 1999, s. 15.

4 P. Filipek, Public Relations w Polsce i na świecie, jej funkcja w zarzadzaniu przedsiębiorstwem (czyli skuteczne komunikowanie) [w:] P. Bielawski, Seminarium z zakresu Komunikacji Społecznej w Zarządzaniu dla kadry kierowniczej KGHM Polska Miedź SA, Świeradów, październik 1996-Szklarska Poręba, styczeń 1997. 
- prewencyjne, czyli powinien przewidywać i zapobiegać działaniom, które wymierzane są przeciw instytucji,

- pomagania w przezwyciężaniu i neutralizowaniu zagrożeń wobec firmy poprzez zmianę kierunku opinii publicznej ${ }^{5}$.

Pierwsze i najbardziej istotne działania PR związane są ze sferą human relations. Polegają na wykreowaniu dobrego i stabilnego wizerunku wśród pracowników przedsiębiorstwa. Nikt tak nie zainteresuje danym podmiotem niezwiązanej z nim osoby jak usatysfakcjonowany i dumny ze swojego przedsiębiorstwa pracownik. Pracobiorca ceniący swoją pracę i przedsiębiorstwo jest najlepszą reklamą w układzie poziomym, czyli między zakładem pracy a środowiskiem, w którym funkcjonuje pracownik. Drugą sferą, która ma ogromne znaczenie dla funkcjonowania firmy, jest corporate identify, czyli wyróżnienie firmy spośród innych w oczach klientów oraz budowanie tożsamości zakładu. Ostatnia $\mathrm{z}$ wymienionych przeze mnie funkcji - obronna - pozwala na długoterminowe działania przedsiębiorstwa $\mathrm{w}$ wypadku powstających zagrożeń. Celem public relations w kłopotliwych sytuacjach jest zwrócenie opinii publicznej na inne, pozytywnie odbierane działania przedsiębiorstwa oraz neutralizacja powstających zagrożeń.

\section{Opinia publiczna jako rodzaj komunikacji międzyludzkiej}

Zjawisko opinii publicznej można rozpatrywać w dwojaki sposób. Pierwszym z nich jest ukazanie opinii publicznej w rozumieniu ilościowym. Jest to bliskie działaniom centrów badania opinii publicznej. Przeciwnicy tego sposobu badania uważają, że na opinię publiczną nie można patrzeć z empirycznego punktu widzenia, ponieważ nie odzwierciedla ona i ignoruje strukturę i działanie operacyjne opinii publicznej.

Każdy pogląd publiczny podlega prawom psychologii zbiorowej. Zasadne jest twierdzenie E. Noelle-Neumann, że każda wyalienowana jednostka dołączy się - z lęku przed dalszym odrzuceniem - do opinii grupy, w ten sposób umacniając i tworząc zafałszowane wyniki' ${ }^{6}$.

Większość definicji opinii publicznej ukazuje podmiotowość opinii i wynikające z niej postawy oraz motywacje ludzkie. Porównując wiele definicji sądu publicznego, można wywnioskować, że „opinia publiczna to zmienny stan świadomości grupowej, składający się z poglądów i przekonań mniej lub bardziej trwałych, odnoszący się do kwestii zazwyczaj dyskusyjnych, których rozwiązanie ma bezpośredni lub pośredni wpływ na aktualne bądź perspektywiczne interesy społeczeństwa"7.

Podsumowując, trudno jest wyciągać daleko idące wnioski z badanej opinii publicznej, ponieważ uzależniona jest ona od indywidualnych do-

5 S. Kuśmierski, Public relations w procesie opiniotwórczym, Warszawa 2006, s. 17.

6 E. Noelle-Neumann, Spirala milczenia, Warszawa 2001, s. 61.

7 S. Kuśmierski, Spirala milczenia..., s. 53. 
świadczeń badanej jednostki, powiązanych z przeżyciami, które są w różny sposób percypowane, a zostały zamknięte w kwestionariuszu.

Podstawowym procesem opiniotwórczym jest proces komunikacji. Stanowi on interakcję, a odbywa się za pomocą mediów bądź indywidualnego obserwowania świata. Można wyróżnić trzy grupy zmiennych psychologicznych wśród badanych społeczeństw. Pierwszą jest postrzeganie świata wokół siebie, fakty, które znamy, zauważamy i przeżywamy w kontrze do tych, które odrzucamy i których nie akceptujemy. Druga grupa to indywidualne oceny tego, jakie poglądy akceptujemy, którym politykom ufamy, jakie przepisy akceptujemy, a jakich nie. Ostatnia z grup to oczekiwania, plany na przyszłość, przypuszczenia, jak zachowają się wobec nas inni lu$\mathrm{dzie}^{8}$. Komunikacja opiera się na obserwacji, myśleniu, czuciu, obejmuje emocje i jest związana $z$ subiektywizmem.

Za pośrednictwem Internetu można zrealizować wszystkie zadania z zakresu PR, a mianowicie możliwa jest bezpośrednia i szybka komunikacja z klientami, pracownikami i partnerami oraz budowanie wizerunku firmy i oferowanego przez nią produktu. Ponadto strony internetowe mają wspierać tradycyjny wizerunek firmy, ułatwiać udostępnianie informacji prasowych, badanie opinii o firmie i oferowanych przez nią produktach oraz przede wszystkim pozwalają efektownie działać w sytuacjach kryzysowych.

Ważnym elementem każdej komunikacji jest manipulacja. Jest to świadome, jak i nieświadome działanie człowieka w celu podjęcia lub zaniechania działań. Dopóki jest ona nieświadoma lub dąży do celu poprzez umiejętne ukazanie osoby lub produktu w taki sposób, żeby podkreślić pozytywne cechy, to jest ona akceptowalna. Natomiast instrumentalne i przedmiotowe traktowanie odbiorcy w celu uzyskania korzyści jest przede wszystkim krótkotrwałe i ociera się o oszustwo.

\section{Kreowanie wizerunku samorządu terytorialnego}

We współczesnym świecie jednostki samorządu terytorialnego przywiązują coraz większą wagę do promocji swoich działań. W ostatnich latach w Polsce można zaobserwować wielkie bilbordy czy reklamy telewizyjne promujące walory poszczególnych województw lub miast. Samorząd terytorialny pełni istotną rolę w życiu społecznym. Konieczność podejmowanych działań PR przez samorządy terytorialne podyktowana jest konkurencją pomiędzy różnymi jednostkami w imię realizacji własnych celów oraz wartości. Nagrodą w tej walce jest kapitał zewnętrzny, zainteresowanie turystów, ludzi kultury i nauki oraz pozyskiwanie funduszy Unii Europejskiej.

8 P.F. Lazarsfeld, Badania opinii publicznej a nauki polityczne, „Kultura i Społeczeństwo" 1986, t. XXX, nr 3, s. 45.

9 M. Skała, Manipulacja odczarowana, Gliwice 2015, s. 15. 
$\mathrm{Na}$ kształtowanie się wizerunku danego samorządu ma wpływ wiele czynników. Przede wszystkim wpływają nań opinie, racjonalne przesłanki oceny działań, jak i emocjonalne poglądy członków danej społeczności. Ważne są uwarunkowania środowiskowe i pozostałości kulturowe. Mieszkańcy poprzez swoje wykształcenie i zaangażowanie w życie danej społeczności dają jej obraz i zachęcają bądź zniechęcają do zainwestowania na danym terenie. Oprócz mieszkańców istotną rolę odgrywa również forma i jakość działań podejmowanych przez władze samorządowe oraz przedsiębiorców. Samorząd terytorialny oceniany jest ze względu na działania i ich efektywność wobec społeczeństwa, partnerskie traktowanie obywateli, a celem komunikacji samorządu z publicznością jest promowanie, informowanie, wyjaśnianie działań, poglądów i idei ${ }^{10}$.

Samorządowe public relations ma na celu dbanie o to, aby eksponować elementy stanowiące o atutach danej jednostki. Akcentowane są nie wszystkie cechy danego samorządu, lecz zbiór cech, dzięki którym dana organizacja staje się rozpoznawalna. Ważne jest to, aby przekazywane informacje były aktualne i wiarygodne oraz aby tworzyły wizerunek otwartości, tożsamości terytorialnej oraz przedsiębiorczości.

Jednym z uprawnień, a zarazem przywilejów jednostek samorządu terytorialnego, jest tworzenie strategii rozwoju. Stanowi ona podstawę działań związanych z PR. Strategia jest procesem, który dąży do realizacji wcześniej zaplanowanego dla danej organizacji celu, jakim jest przezwyciężenie konkurencji, wzrost pozycji na rynku czy rozwój. Głównym celem kreowania wizerunku publicznego $\mathrm{w}$ samorządzie jest rzetelna informacja, dostarczanie wiedzy na temat działań oraz kompleksowa oferta korzyści skierowana do potencjalnych mieszkańców bądź inwestorów, która powinna być ściśle powiązana ze strategią rozwoju danego samorządu. Zmagania te powinny pozwalać odbiorcom na wyrażanie opinii i ich oczekiwań oraz wymianę poglądów, bowiem stanowi to podstawę systemów demokratycznych, a pomiędzy organami władzy i społecznością powinny stwarzać warunki do wzajemnego porozumienia.

Oprócz kreowania wizerunku na zewnątrz samorządu terytorialnego ważna jest też wewnętrzna komunikacja $\mathrm{z}$ zamieszkującymi i pracującymi w danych jednostkach osobami oraz z prosperującymi na tym terenie przedsiębiorstwami. Powinna ona przede wszystkim dążyć do partnerstwa w zarządzaniu, wzajemnej zgodności i wizji dążenia. Celem tych zadań musi być kształtowanie społecznej aktywności w kierunku współuczestnictwa mieszkańców w decyzyjności władz.

Każda kreacja wizerunku publicznego jednostek samorządu terytorialnego powinna być odpowiednio dostosowana do cech odbiorcy i specyficznego jej postrzegania w kraju bądź zagranicą. Podejmowane przez

10 R. Maćkowska, Znaczenie kreowania wizerunku samorzadu terytorialnego [w:] Public relations instytucji użyteczności publicznej, E. Hope (red.), Gdańsk 2005, s. 198. 
władze samorządowe działania PR powinny budować atmosferę zaufania, stwarzać szansę na porozumienie przy podejmowaniu decyzji w sprawie działań kontrowersyjnych czy trudnych dla danej jednostki.

\section{Mierzenie efektywności PR}

Trudnym tematem $\mathrm{w}$ działaniach public relations jest mierzenie ich efektywności. Odbywa się ono w ten sam sposób dla prywatnych przedsiębiorstw, jak i dla gmin. Aktywność PR nie powinna polegać tylko na wysyłaniu komunikatu. Należy także sprawdzić, jaki wpływ wywarły podjęte działania na publiczności, czyli odczytać komunikat zwrotny (zmierzyć efektywność PR). W rzetelnym zmierzeniu powracających informacji przeszkadzają dwa czynniki. Pierwszy z nich jest natury strukturalnej, gdy skutki działań mają być trwałe, lecz odsunięte w czasie. Trudno zbadać, jaką w danym momencie organizacja posiada reputację. Drugim z problemów są bariery techniczne, które mogą wynikać ze zbyt małej ilości funduszy przeznaczonych na zbadanie efektywności działań. Na podstawie badań przeprowadzonych w 2004 r. przez portal „PR Week” wykazano, że tylko $4 \%$ światowych przedsiębiorstw przeznacza na zbadanie efektywności dzialań PR więcej niż 10\% budżetu przeznaczonego na same działania, a ocena efektywności (tych $4 \%$ czy pozostałych przedsiębiorstw) w dużej mierze jest intuicyjna ${ }^{11}$.

Właściwy pomiar skuteczności działań mających na celu budowania wizerunku publicznego uzależniony jest od dobrze zdefiniowanych celów. Wzorowo zdefiniowane cele powinny być: szczegółowe i dokładne, mierzalne, możliwe do osiągnięcia, zorientowane na rezultaty oraz ograniczone w czasie.

Gdy cel związany jest ze zwróceniem uwagi na dane przedsiębiorstwo czy urząd, produkt lub inne zjawisko, należy mierzyć go za pomocą częstości kontaktu z komunikatem, np. liczbą osób, które odwiedziły stronę internetową, zadzwoniły na infolinię bądź wysłały e-maile. Jeżeli celem jest wpływanie na opinię i przekazywanie informacji, to najlepszym sposobem zmierzenia będą badania społeczne jakościowe oraz ilościowe, czyli różnego rodzaju ankiety, wywiady pogłębione. Trzecim cel, jaki można założyć, to wpływanie na postawy i decyzje, a zmierzenie stopnia jego realizacji odbywa się za pomocą obserwowania konkretnych zachowań adresatów komunikacji, np. poprzez obserwowanie rotacji zatrudnienia.

Wyniki są szybkim i bezpośrednim rezultatem działań, występują w krótkich projektach związanych z przedstawieniem instytucji. Zmierzyć je można za pomocą ustalenia ilości rozdanych ulotek, powołań nazwy organizacji w mediach, ilości osób odwiedzających jej stronę internetową czy poprzez ilość osób zainteresowanych stanowiskiem na targach. Mierząc

11 Dane ze strony internetowej: http://www.prweek.com/ (dostęp: 16.05.2016). 
efekty, należy szukać odpowiedzi na pytanie, czy działanie zostało zrozumiane i w jaki sposób zostało odebrane. Efekty dotyczą projektów długoterminowych. Zmierzyć można je za pomocą zmian cen akcji przedsiębiorstwa, ilości zebranych pieniędzy przez fundację oraz poprzez liczbę opinii na temat organizacji i jej reputację w Internecie ${ }^{12}$.

\section{Założenia metodologiczne}

Przedmiotem prowadzonych przeze mnie badań jest wizerunek publiczny Urzędu Miasta Krakowa. Celem badania jest ukazanie, w jaki sposób postrzegają Urząd klienci, a jak widzą go jego pracownicy. Podejmę próbę odpowiedzi na pytanie o możliwe przyczyny zaistniałych różnic.

Hipotezy, jakie sformułowałam na potrzeby niniejszego artykułu, są następujące:

1) klienci postrzegają urząd bardziej krytycznie niż pracownicy,

2) pracownicy i klienci nie są obiektywni w swoich ocenach,

3) ocena wyrażona przez pracowników jest bardzo zachowawcza i delikatna,

4) ocena wyrażona przez pracowników i ocena wyrażona przez klientów w znaczącym stopniu się różnią.

W celu przeprowadzenia swoich badań skorzystałam $\mathrm{z}$ dwóch ankiet. Pierwsza $\mathrm{z}$ nich jest gotowym raportem $\mathrm{z}$ badań ilościowych przeprowadzonych w Urzędzie Miasta Krakowa w 2015 r. przez zewnętrznego wykonawcę i dotyczy ona poziomu satysfakcji klientów Urzędu. Ankieta zawierała 16 pytań zamkniętych i 4 otwarte. Z puli tych pytań wykorzystałam tylko odpowiedzi na pytania, które zadałam pracownikom Urzędu. Średni czas trwania badania satysfakcji klienta to $6 \mathrm{~min}$. Druga z ankiet, stworzona przeze mnie, została przeprowadzona w kwietniu 2016 r. wśród pracowników Urzędu Miasta Krakowa. Zawierała 4 pytania zamknięte oraz 3 pytania znajdujące się w metryczce. Średni czas przeznaczony na wypełnienie ankiety to 3-4 min. Zarówno w pierwszej, jak i drugiej ankiecie została zastosowana pięciopunktowa skala odpowiedzi: 5 - bardzo dobrze, 4 - raczej dobrze", 3 - raczej źle, 2 - bardzo źle, 1 - nie mam zdania. Badane osoby zostały wybrane losowo.

Badania zostały przeprowadzone w 19 punktach obsługi 11 Wydziałów Urzędu Miasta Krakowa. Łącznie zostało poproszonych o wypełnienie ankiety 830 osób. W znacznej większości badani sami wypełniali ankiety, a w nielicznych sytuacjach (osoby starsze) w wypełnieniu ankiety pomagał ankieter. Badania trwały 2 tygodnie.

12 R. Szymczak, Mierzenie efektywności w PR: Trudne nie znaczy niemożliwe [w:] Sztuka public relations. $Z$ doświadczenia polskich praktyków, Warszawa 2011, s. 326-327. 


\section{Charakterystyka grupy badawczej}

W badaniach dotyczących satysfakcji klienta udział wzięło 800 osób. W większości były to kobiety - 53\% badanych. Większość respondentów stanowiły osoby w wieku powyżej 40 lat). $85 \%$ badanych posiada wykształcenie wyższe.

Wykres 1. Płeć respondentów

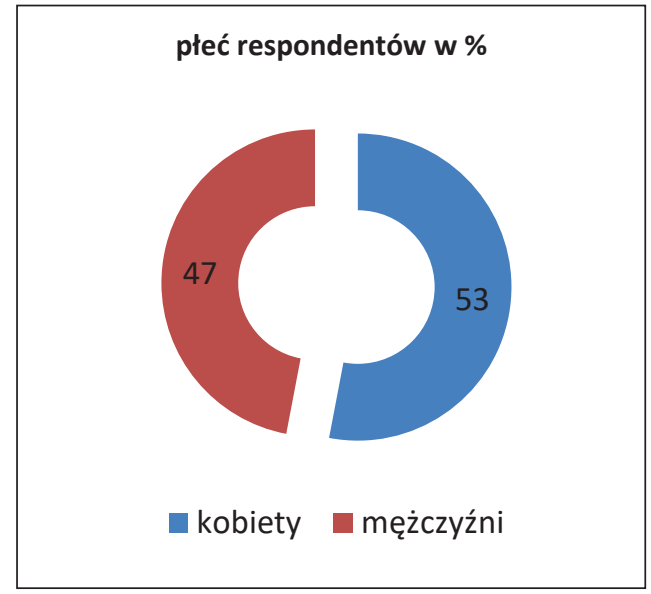

Źródło: opracowanie własne.

Wykres 2. Wiek badanych $\mathrm{w}$ procentach $\mathrm{z}$ raportu badań ilościowych $\mathrm{z}$ raportu satysfakcji klienta

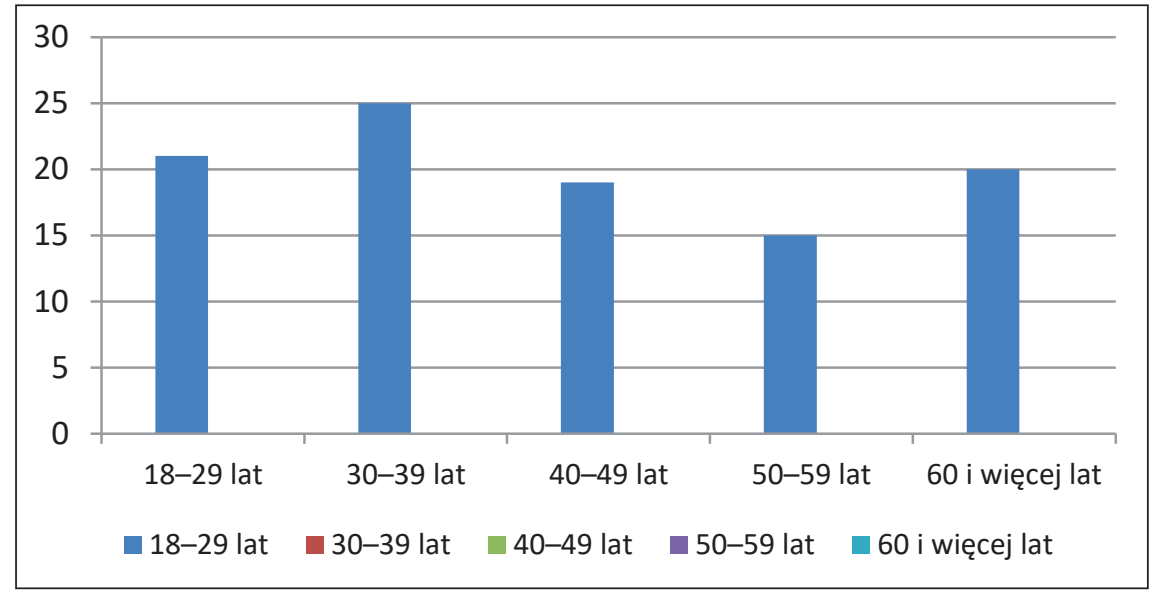

Źródło: opracowanie własne. 
Wykres 3. Płeć badanych pracowników

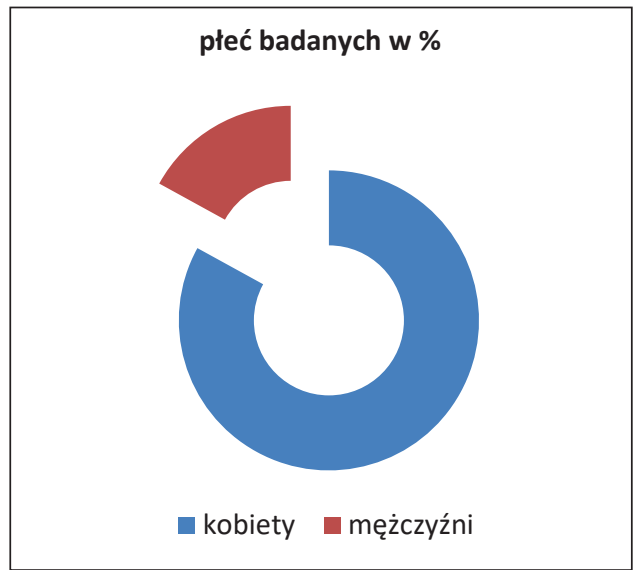

Źródło: opracowanie własne.

Wykres 4. Wiek badanych pracowników w procentach

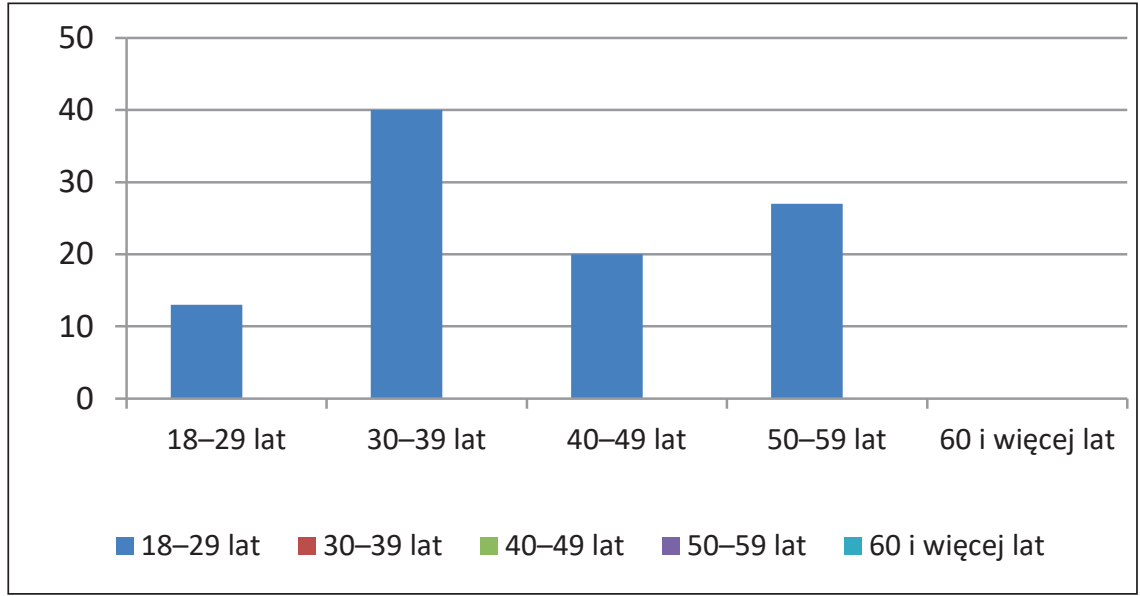

Źródło: opracowanie własne.

W ankiecie skierowanej do pracowników Urzędu Miasta wzięło udział 30 osób, z czego 25 to kobiety. 40\% z badanych pracowników jest w wieku między 30 a 39 rokiem życia. Ponad połowa ankietowanych posiada wyższe wykształcenie.

Powierzchnia miasta Krakowa wynosi $327 \mathrm{~km}^{2}$, jest ono podzielone na 18 dzielnic. Szacowana liczba mieszkańców na 31 grudnia 2015 r. wynosiła 761 tys. $^{13}$

13 Zob. https://www.bip.krakow.pl/?bip_id=1\&mmi=97 (dostęp: 15.05.2016). 
Główna siedziba Urzędu Miasta znajduje się przy Placu Wszystkich Świętych 3-4, lecz budynki urzędowe znajdują się w każdej z dzielnic.

\section{Postrzeganie Urzędu przez klientów}

Wykres 5. Obsługa klienta związana z pracą urzędników

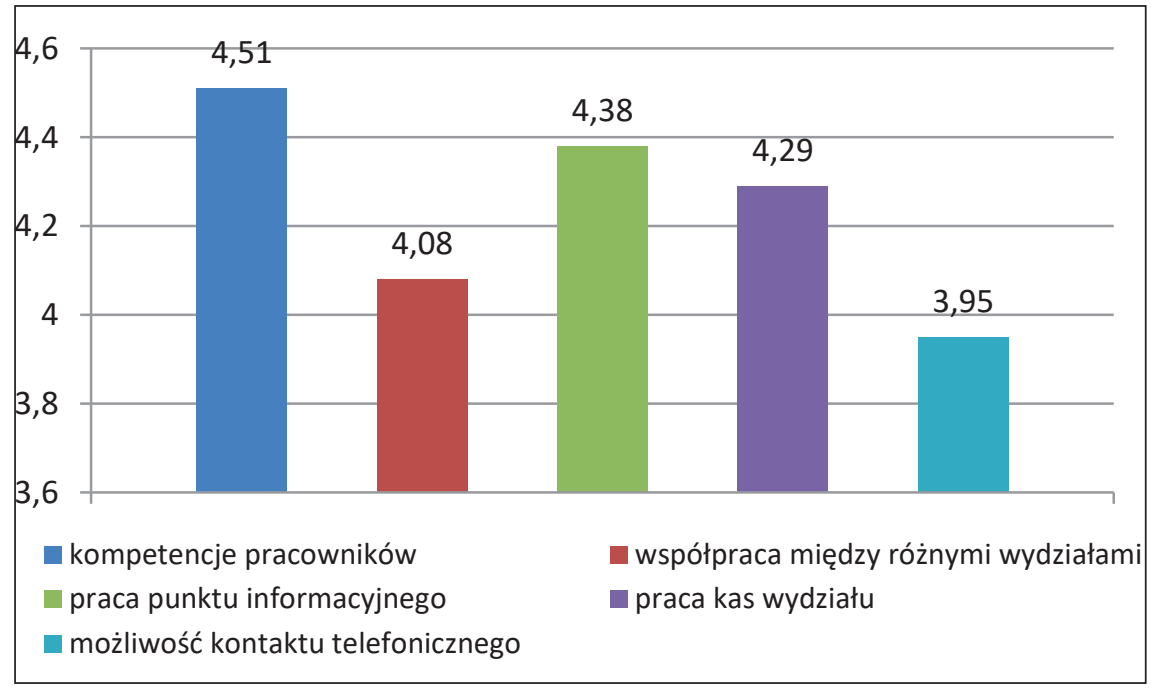

Źródło: opracowanie własne.

Wszystkie osoby mające do załatwienia sprawy urzędowe, wychodząc z budynku Urzędu mają już wyrobioną opinię na temat jego funkcjonowania. W pierwszej kolejności przedstawione są te wartości, które dotyczą fizycznej obsługi interesanta, czyli kompetencji pracowników, obsługi telefonicznej i innych.

Najwyżej zostały ocenione przez badanych kompetencje urzędników oraz praca punktu informacyjnego i kas wydziału. Wynik może być spowodowany tym, że klienci nie zawsze orientują się w ciągle rosnącej liczbie przepisów prawnych, a pracownicy ze względu na swoje obowiązki muszą im wszystko wytłumaczyć. Wysoka ocena pracy punktu informacyjnego i kas wydziałowych może być związana z charakterem załatwianych spraw - zazwyczaj są to szybkie wpłaty, krótkie informacje, które nie powodują frustracji wśród klientów. Najgorzej został oceniony kontakt telefoniczny. Wynik ten pokazuje, że pomimo nieodbieranych rozmów telefonicznych urzędnicy nie oddzwaniają do telefonujących, co budzi niechęć i zdenerwowanie.

Kolejne pytania zadane ankietowanym odnoszą się do budynków UMK, w jakich obsługiwani są interesanci. 
Wykres 6. Warunki techniczne budynków oraz udogodnienia dla interesantów

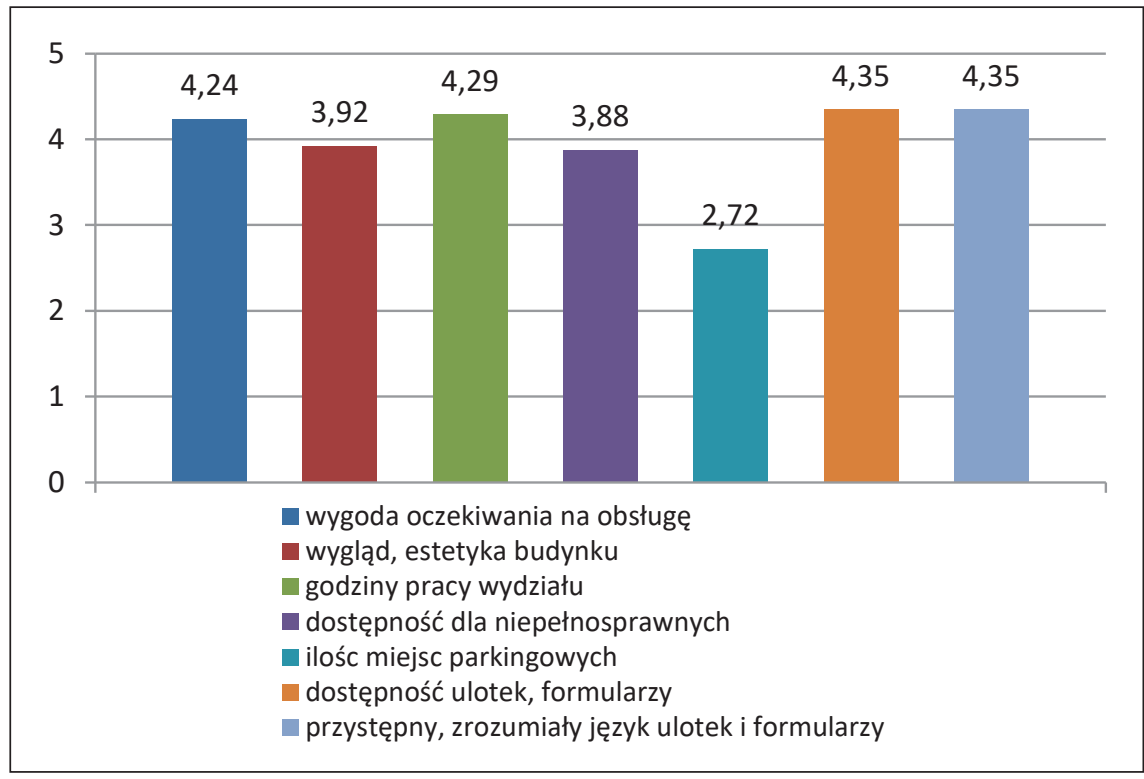

Źródło: opracowanie własne.

Najbardziej satysfakcjonujące wyniki dotyczą wygody i wyglądu miejsc, w których interesanci oczekują na obsługę (poczekalni), godzin pracy wydziałów, dostępności ulotek informacyjnych, formularzy oraz dostępności języka, w jakim są napisane. Znacznie mniej satysfakcjonują opinie dotyczące wyglądu budynków oraz dostępności tych budowli dla osób niepełnosprawnych. Wiele budynków, w których funkcjonuje UMK, zostało wybudowanych w latach 50. i 60. Jakkolwiek są one modernizowane i remontowane, to nie wszystkie posiadają windy i podjazdy dla niepełnosprawnych. Najgorzej ocenionym elementem są parkingi dla klientów. Wskazuje się na brak parkingów (płatnych i bezpłatnych) w okolicach wielu budynków UMK, a w przypadkach gdy takie parkingi są, na ich małą pojemność - przystosowanie dla kilku samochodów, co nie jest adekwatne do liczby wydziałów w budynku.

Kolejne pytanie dotyczyło tego, jaka jest - zdaniem ankietowanego liczba pracowników obsługujących poszczególne wydziały.

Otrzymany wynik jest zadowalający - wbrew negatywnym opiniom na temat zatrudnienia w sferze budżetowej, aż 79\% badanych uważa, że liczba osób pracujących w Urzędzie Miasta Krakowa jest wystarczająca bądź za wysoka. $21 \%$ badanych wskazało, że liczba ta jest zbyt niska. Wynik ten może ukazywać zadowolenie klientów z obsługi oraz wywiązywanie się pracowników z większości terminów realizacji danych spraw. Alarmujący powinien być wynik wskazujący na zbyt małą liczbę pracowników, gdyż 
Wykres 7. Liczba zatrudnionych pracowników w UMK według opinii klientów

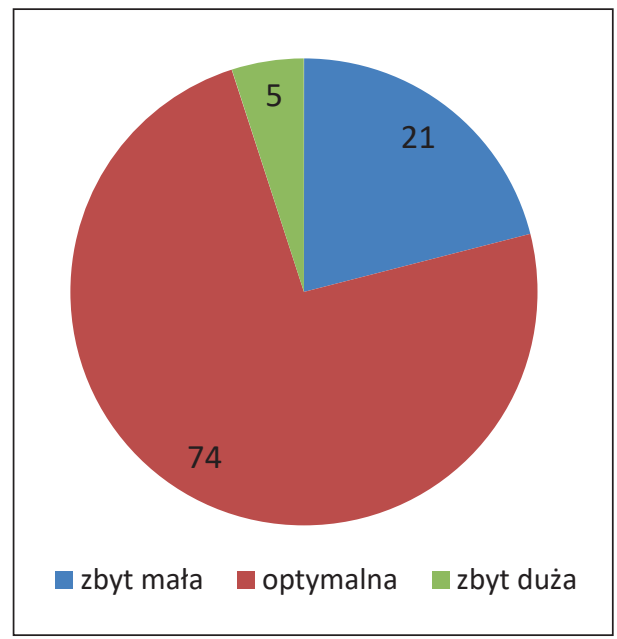

Źródło: opracowanie własne.

Wykres 8. Częstotliwość korzystania ze strony internetowej Urzędu przez klientów

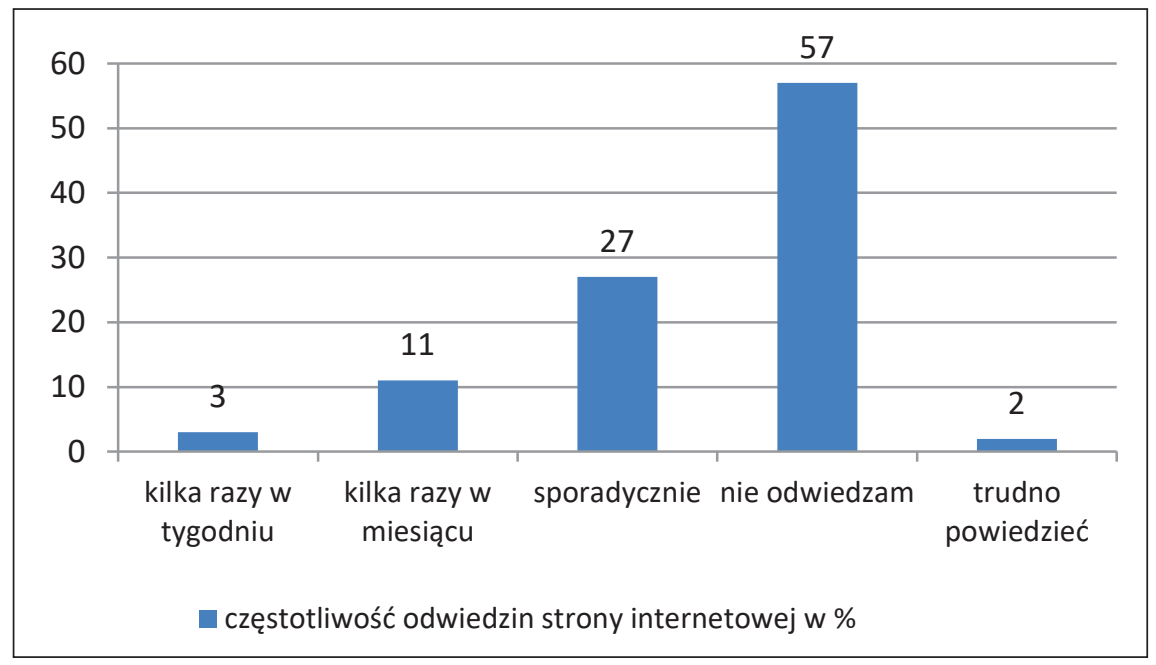

Źródło: opracowanie własne.

oznaczać może wydłużony czas oczekiwania na załatwienie sprawy. Kolejne pytania dotyczyły strony internetowej Urzędu Miasta Krakowa.

Okazało się, że 57\% badanych nie korzysta ze tej strony internetowej. Sporadycznie wykorzystuje ją $27 \%$ badanych. Wynik ten dowodzi, że większość klientów przychodzi do Urzędu nieprzygotowana, nie znając procedur oraz druków urzędowych. Niewątpliwie zapoznanie się z potrzebnymi 
informacjami na stronie internetowej przed odwiedzeniem Urzędu mogłoby przyczynić się do przyspieszenia i skrócenia czasu obsługi.

Następne pytania ściśle odnosiły się do wyglądu strony internetowej i informacji w niej zawartych.

Wykres 9. Informacje dotyczące strony internetowej UMK według interesantów

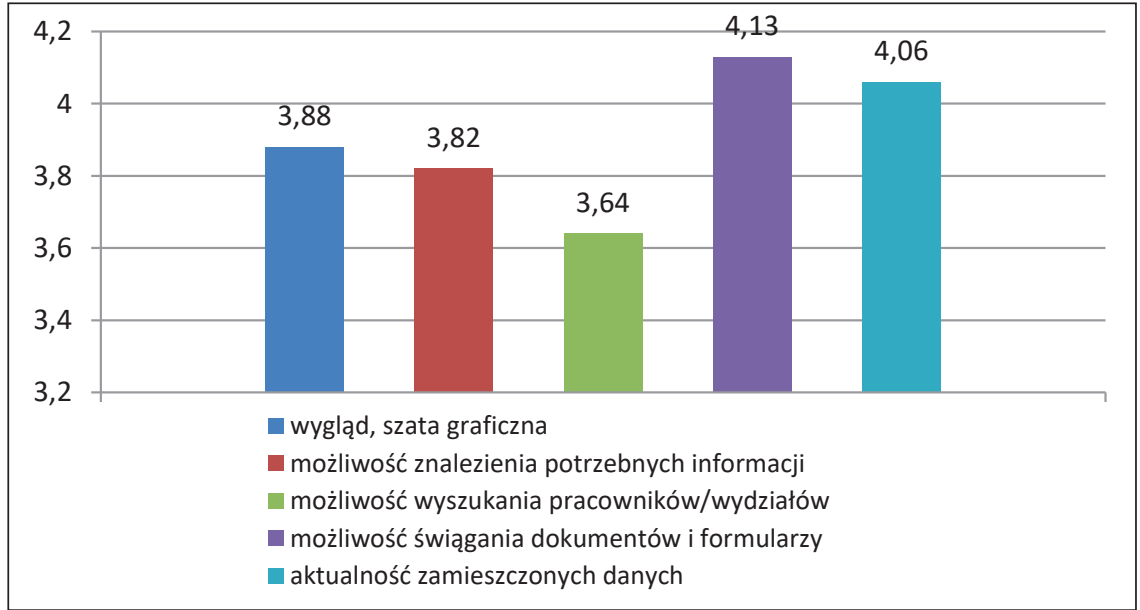

Źródło: opracowanie własne.

Spośród przedstawionych możliwości najwyżej zostały ocenione możliwość ściągania plików i formularzy oraz aktualność zamieszczonych danych. W funkcjonowaniu strony internetowej ważne jest, aby klienci na bieżąco wiedzieli, co dzieje się w gminie. Szata graficzna, jak i możliwość znalezienia potrzebnych informacji i wyszukania pracowników łączą się ze sobą, stąd przybliżone wyniki. Strona Urzędu Miasta Krakowa jest stroną Biuletynu Informacji Publicznej. Strony te są mają ujednolicony w całym kraju charakter i nie dają większej możliwości ingerencji w ich wygląd oraz rozmieszczenie danych.

\section{Postrzeganie Urzędu przez pracowników}

Badana grupa pracowników udzielała odpowiedzi na te same pytania ankietowe co badani klienci. W pierwszym zadanym pytaniu pracownicy mieli ocenić kompetencje swoich współpracowników.

Z uzyskanych danych wynika, że współpracownicy bardzo wysoko oceniają wzajemnie swoje kompetencje, tylko jedna $z$ badanych osób udzieliła odpowiedzi, że są one raczej złe. Wynik ten potwierdza jakość kompetencji pracowników Urzędu Miasta Krakowa oraz lojalność wśród pracowników. 
Wykres 10. Kompetencje współpracowników

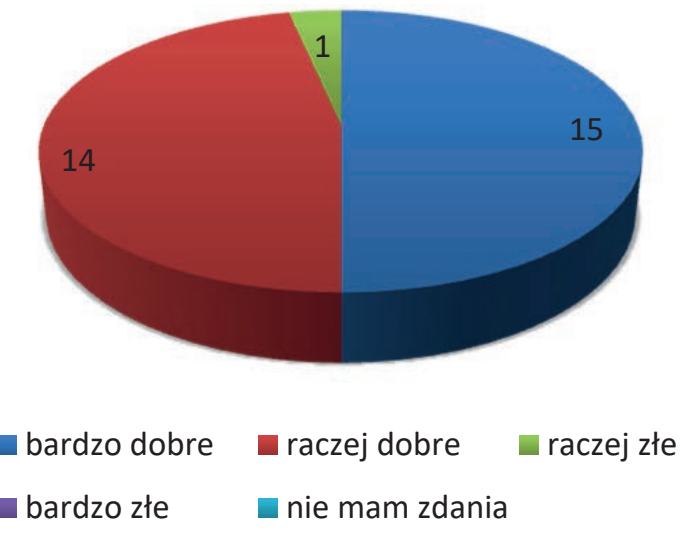

Źródło: opracowanie własne.

Wykres 11. Wygoda oczekiwania na obsługę w miejscu pracy oraz wygląd i estetyka budynku według pracowników

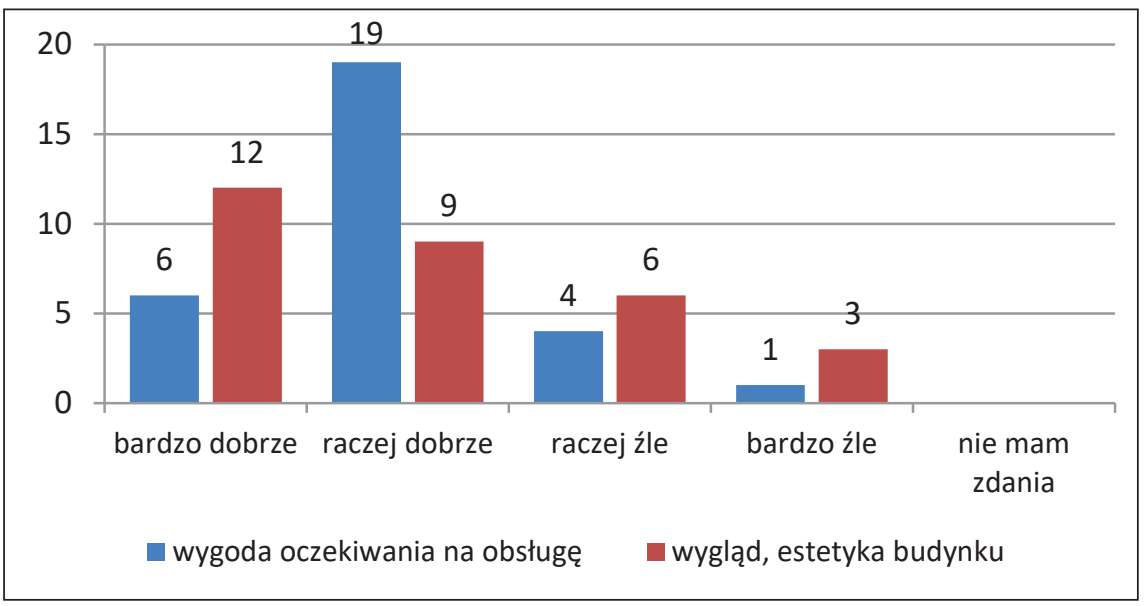

Źródło: opracowanie własne.

Kolejnymi pytaniami skierowanymi do pracowników były te dotyczące wygody oczekiwania na obsługę w miejscu pracy oraz ogólnego wyglądu i estetyki budynku.

Z przedstawionego materiału wynika, że zdania pracowników na temat zewnętrznego wyglądu budynku, w którym pracują, oraz wyglądu poczekalni dla klientów są podzielone. Różnice wynikać mogą z tego, że ankietowani są pracownikami różnych wydziałów, rozmieszczonych w różnych 
budynkach, jedni pracują w starszych, inni w nowszych biurach. Wśród opinii przeważa ta, że budynki wyglądają raczej dobrze i dobrze.

Następne pytanie dotyczyło godzin pracy wydziałów, współpracy urzędników między różnymi wydziałami oraz kontaktu telefonicznego między wydziałami. Większość wydziałów czynna jest od godziny 7.30 do 15.30, z wyjątkiem Wydziału Ewidencji Ludności i Dowodów Osobistych oraz Wydziału Komunikacji, gdzie sprawę można załatwiać od godziny 7.30 do 18.00 .

Wykres 12. Godziny pracy wydziału, kontakt telefoniczny między wydziałami oraz współpraca urzędników między wydziałami

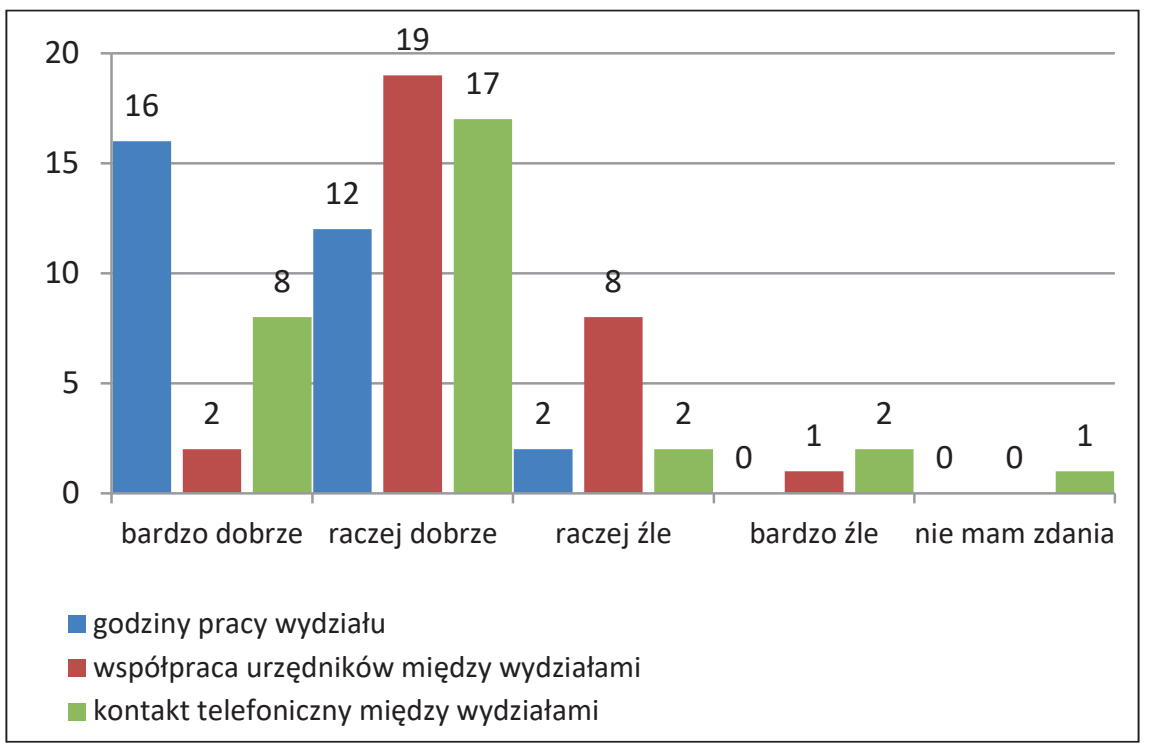

Źródło: opracowanie własne.

W pierwszej kolejności uwagę zwraca mała wzajemna pomoc między pracownikami. tylko dwie badane osoby wskazały, że ta współpraca jest bardzo dobra. Aż 9 na 30 badanych osób ocenia ją źle lub bardzo źle. Nie wiadomo, skąd wynika wzajemna niechęć do pomocy i współpracy. Lepiej wyglądają już kontakty telefoniczne wśród pracowników różnych jednostek, ponieważ znacząca większość badanych jest $\mathrm{z}$ nich zadowolona. Godziny prac poszczególnych wydziałów urzędnicy określają jako dobre i bardzo dobre, chodź z pewnością są wydziały, które mogłyby mieć wydłużone godziny pracy, lecz wtedy satysfakcja pracowników zapewne byłaby mniejsza.

W następnej kolejności ankietowani odpowiedzieli na pytanie, jaki według nich mają dostęp do urzędu osoby niepełnosprawne oraz czy ilość miejsc parkingowych dla interesantów przed budynkami jest wystarczająca. 
Wykres 13. Dostępność wydziałów dla osób niepełnosprawnych oraz ilość miejsc parkingowych przed budynkiem

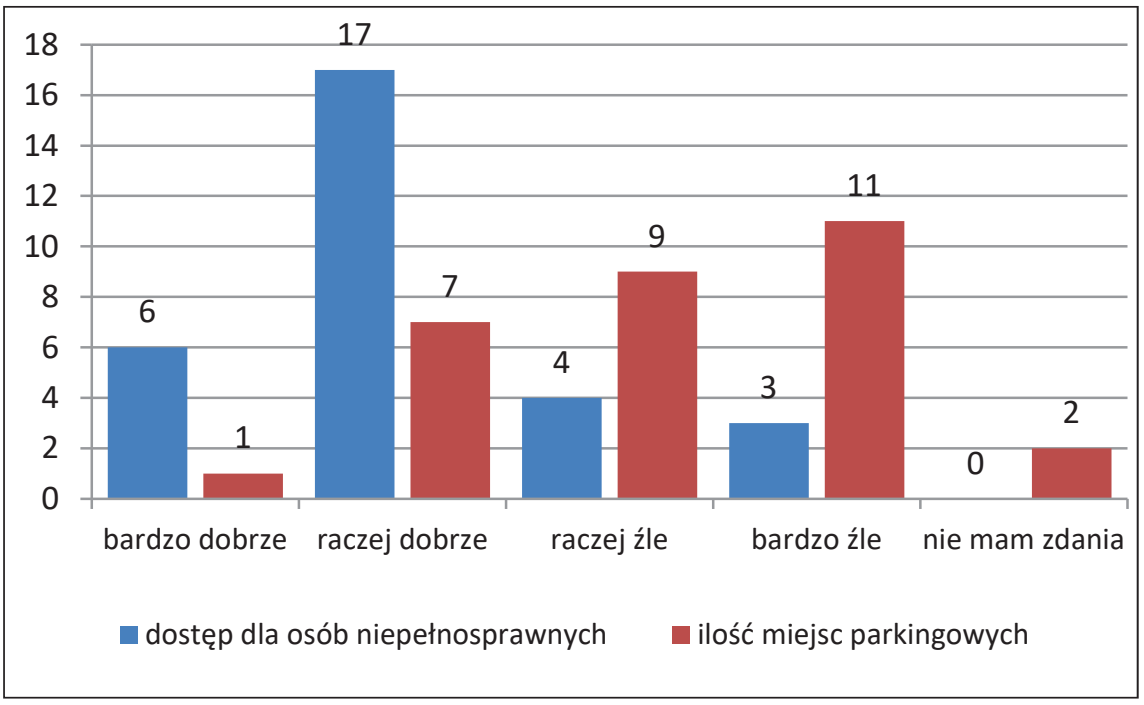

Źródło: opracowanie własne.

$\mathrm{Z}$ udzielonych odpowiedzi wynika, że osoby niepełnosprawne mają dobry dostęp do wydziałów, a 25\% ankietowanych dostęp uważa za zły. Wynik ten spowodowany może być tym, że odpowiedzi udzielane były przez pracowników jednostek ulokowanych w starych piętrowych budynkach bez windy. Pomimo że takich budynków UMK jest niewiele, to jeszcze funkcjonują, a przeszkody techniczne nie pozwalają na zrobienie udogodnień dla osób niepełnosprawnych.

Pytanie o parking dla interesantów przy budynku wydziału wzbudziło wiele emocji wśród pytanych. Aż 20 na 30 osób ocenia źle i bardzo źle przy wydziałowe parkingi, a 2 osoby nie wyraziły zdania. Wiele budynków Urzędu Miasta w Krakowie znajduje się w ścisłym centrum, gdzie nie ma parkingów lub są tylko parkingi płatne z bardzo wysoką stawką godzinową. Nawet przy budynkach w innych dzielnicach niż Śródmieście parkingi przy budynkach są niewielkie, a w biurowcach znajduje się kilkanaście wydziałów. Brakuje również parkingów dla pracowników.

Następnym poruszonym tematem była praca punktu informacyjnego i kas obsługujących wydział.

Odpowiedzi na obydwa pytania są różne. Powodem może być to, że nie każdy wydział w Urzędzie posiada kasę i punkt informacyjny. Brak kas spowodowany jest tym, że operacje finansowe odbywają się za pomocą przelewów bankowych. Zamiast punktów informacyjnych w wielu budynkach jest portiernia, gdzie ochrona ma obowiązek udzielić interesantom odpowiedzi na zadane pytania, więc punkt informacyjny staje się zbędny. 
Wykres 14. Praca punktu informacyjnego i kas obsługujących wydział

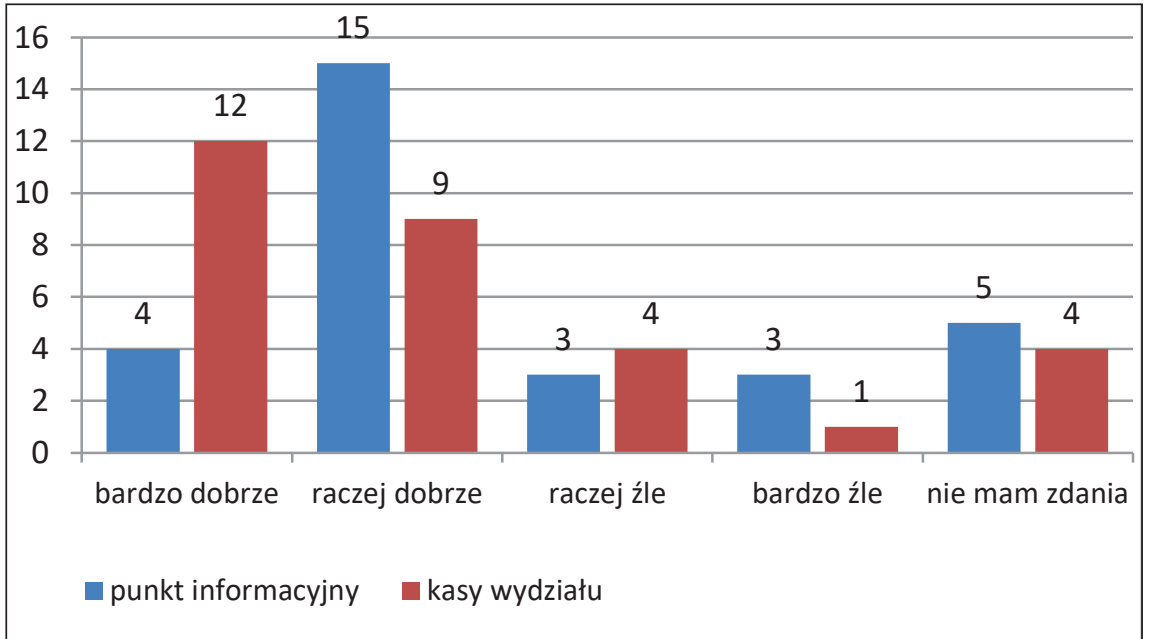

Źródło: opracowanie własne.

Wykres 15. Dostępność ulotek i formularzy w Urzędzie oraz język, w jakim są one napisane

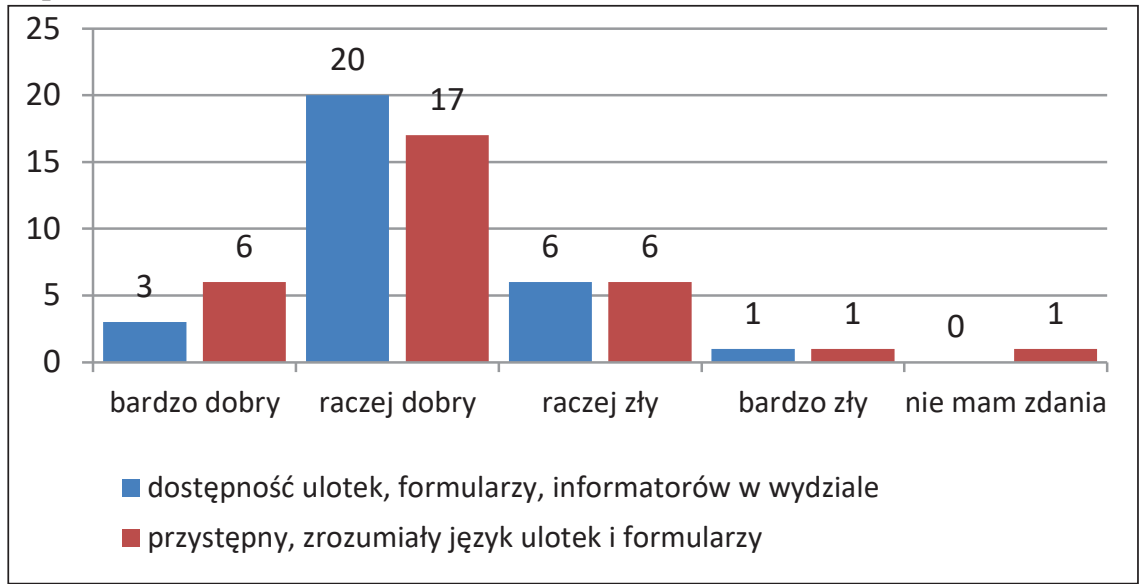

Źródło: opracowanie własne.

Ważnym elementem w urzędach są informatory i ulotki, które pozwalają interesantom na zapoznanie się z tematem przed zaczęciem załatwiania spraw. Kolejne pytanie dotyczyło dostępności ulotek i formularzy w Urzędzie oraz języka, w jakim są one napisane.

W znacznej większości pracownicy pozytywnie ocenili dostęp formularzy i ich język. Wynikać to może z tego, że pracownicy zajmujący się danymi dziedzinami na co dzień bez problemu rozumieją dane zapisane $\mathrm{w}$ informatorach. 
Wydawać by się mogło, że sfera budżetowa $\mathrm{z}$ miesiąca na miesiąc się rozrasta, a pracy nie ubywa. W UMK pracuje około 2200 osób, konkursy na wolne stanowiska w różnych jednostkach są ogłaszane w każdym miesiącu.

Wykres 16. Ilość zatrudnionych pracowników w UMK według opinii zatrudnionych

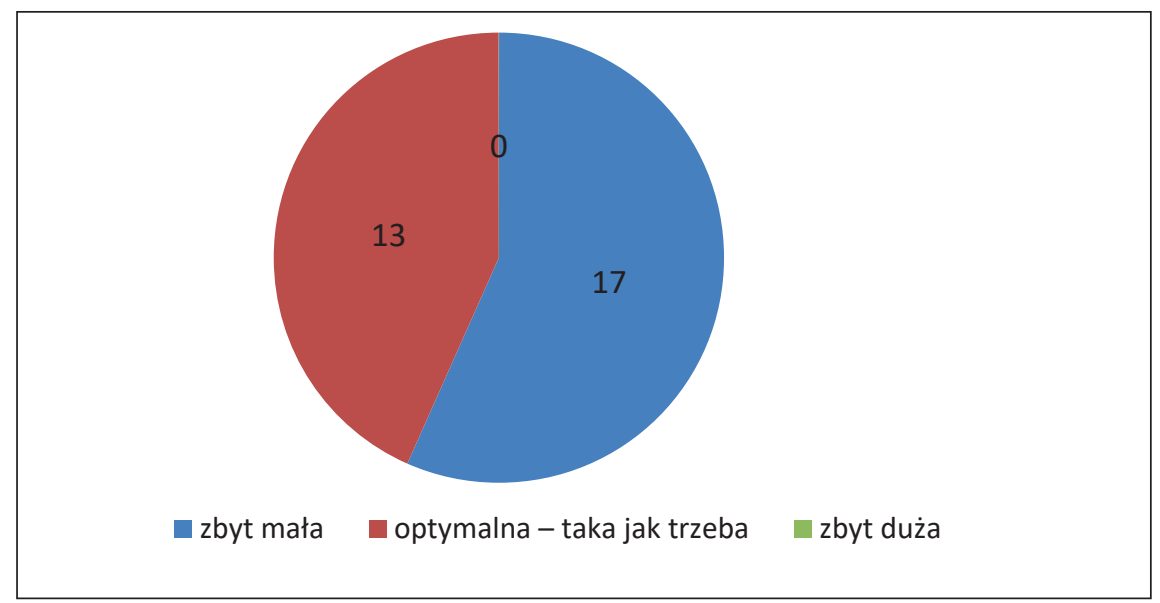

Źródło: opracowanie własne.

Żaden z pracowników nie wskazał, że liczba zatrudnionych jest zbyt niska, być może ze strachu, że wyniki mogą przyczynić się do redukcji etatów. Prawie połowa badanych uważa, że liczba jest wystarczająca i optymalna, a ponad połowa respondentów sądzi, że zatrudnionych jest zbyt mało osób. Odpowiedź ta może być związana z ciągle zmieniającymi się przepisami prawnymi, koniecznością spełniania wymogów ISO czy Unii Europejskiej, które nakładają na pracowników coraz więcej pracy.

Jedno $\mathrm{z}$ ostatnich pytań, na które odpowiedzieli badani pracownicy, dotyczyło częstotliwości odwiedzania strony internetowej. Pytanie było swobodnie skonstruowane, nie nakładało na pracownika rozróżnienia na korzystanie ze strony dla potrzeb służbowych i prywatnych.

W tych odpowiedziach zatrudnieni podzielili się na dwie grupy: tych, którzy często i kilka razy w miesiącu korzystają ze strony UMK (ponad połowa) oraz tych, którzy sporadycznie bądź wcale jej nie używają - 13 osób. Podział ten może dowodzić, że najwięcej korzystają ze strony Ci, którzy potrzebują danych na niej umieszczonych w swojej pracy bądź wykorzystują ją do załatwiania spraw interesantów. Druga grupa najprawdopodobniej wykorzystuje stronę internetową Urzędu Miasta Krakowa do zrealizowania własnych potrzeb jako klienci UMK.

Ostatnie pytania odnoszą się do informacji zamieszczanych na stronie internetowej Urzędu Miasta oraz szaty graficznej tej strony. 
Wykres 17. Częstotliwość korzystania ze strony internetowej Urzędu przez pracowników

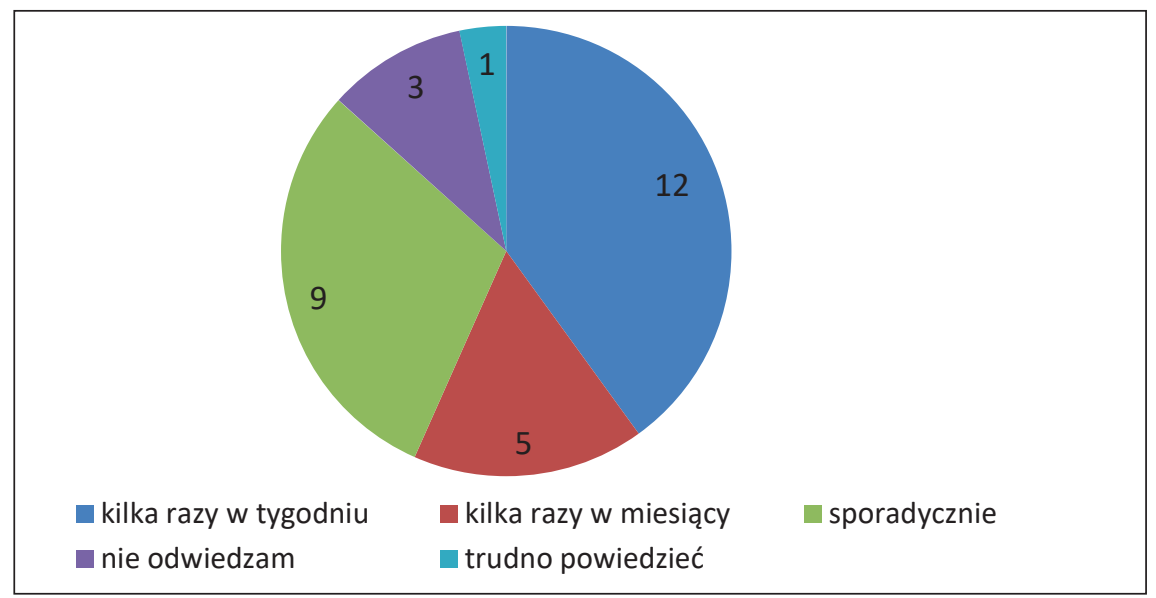

Źródło: opracowanie własne.

Wykres 18. Informacje dotyczące strony internetowej UMK według pracowników

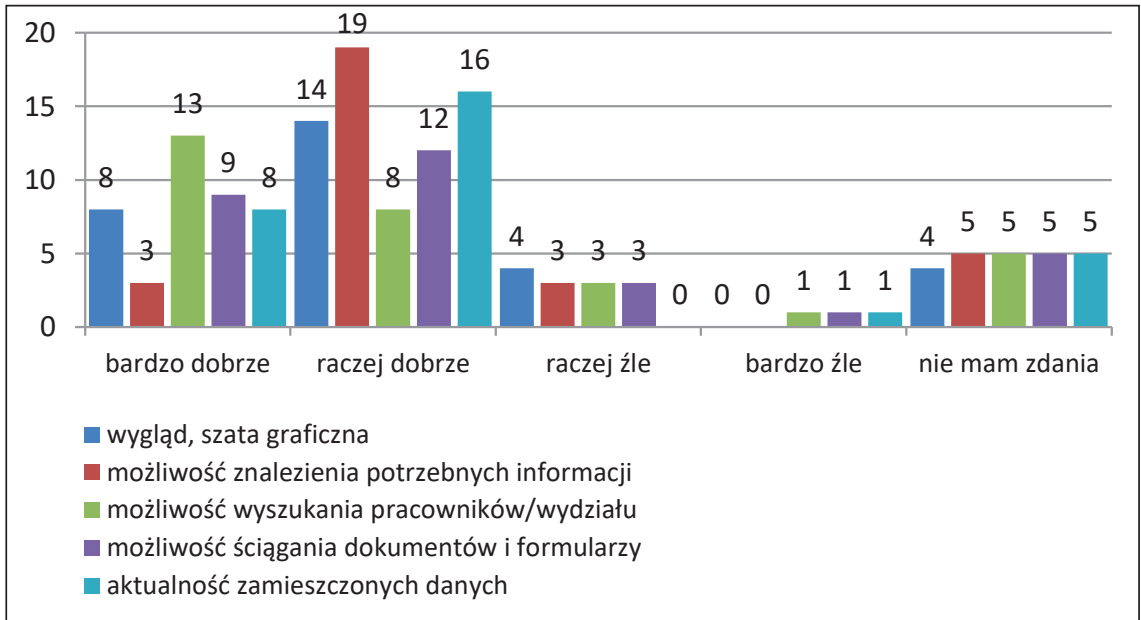

Źródło: opracowanie własne.

Z uzyskanych informacji wnioskuję, że wysoko ocenione zostały wszystkie wymienione kategorie dotyczące strony internetowej Urzędu, lecz w każdym pytaniu ponad 15\% badanych stwierdziło się, że nie ma ten temat zdania. Odpowiedzi te wynikają z pytania poprzedniego, dotyczącego częstotliwości odwiedzania internetowego serwisu, gdzie $45 \%$ badanych przyznało się do sporadycznego odwiedzania strony bądź do niekorzystania $\mathrm{z}$ niej wcale. 


\section{Różnice i podobieństwa w postrzeganiu Urzędu}

W badaniach założono, że wizerunek Urzędu będzie bardziej negatywnie oceniony przez interesantów, a pozytywnie przez pracowników. Rozpoczynając weryfikację tego założenia, warto przedstawić wyniki dotyczące kompetencji pracowników.

Tabela 1. Porównanie średniej wyników dotyczących obsługi przez pracowników

\begin{tabular}{|l|c|c|}
\hline \multicolumn{1}{|c|}{ KATEGORIA ODPOWIEDZI } & KLIENCI & PRACOWNICY \\
\hline Kompetencje pracowników & 4,51 & 4,46 \\
\hline Współpraca między wydziałami i urzędnikami & 4,08 & 3,73 \\
\hline Praca punktu informacyjnego & 4,38 & 3,33 \\
\hline Praca kas obsługujących wydział & 4,29 & 3,8 \\
\hline Możliwość kontaktu telefonicznego & 3,95 & 4,1 \\
\hline
\end{tabular}

Źródło: opracowanie własne.

Wskazane dane ukazują, że klienci są bardziej zadowoleni z obsługi i działania danego wydziału niż sami pracownicy. Jedynie kompetencje pracowników i możliwość kontaktu telefonicznego wskazują na przewagę po stronie pracowników. Jest widoczne, że pracownicy częściej odbierają telefony od innych współpracowników niż od zainteresowanych stron, co może być związane z potrzebą uzyskania informacji koniecznych do rozstrzygnięcia sprawy, z którą przyszedł dany klient. Gorsza ocena przez pracowników punktu informacyjnego i pracy kas może być spowodowana charakterem pracy i kontaktów między tymi działami. Interesant, który zapyta o coś w punkcie informacyjnym i uzyska informację, jest usatysfakcjonowany. Dopiero gdy udaje się do niewłaściwej osoby w calu załatwienia swojej sprawy, dowiaduje się, że pokój nie jest odpowiedni, lecz i tak często wnioski przyjmowane są przez osoby, do których klienci zostali skierowani przez punkt informacyjny.

Tabela 2. Porównanie średniej wyników dotyczących warunków w budynkach UMK

\begin{tabular}{|l|c|c|}
\hline \multicolumn{1}{|c|}{ KATEGORIA ODPOWIEDZI } & KLIENCI & PRACOWNICY \\
\hline Wygoda oczekiwania na obsługę & 4,24 & 4,0 \\
\hline Wygląd, estetyka budynku & 3,92 & 4,06 \\
\hline Godziny pracy wydziału & 4,29 & 4,46 \\
\hline Dostępność dla osób niepełnosprawnych & 3,88 & 3,86 \\
\hline Ilość miejsc parkingowych dla interesantów & 2,72 & 2,7 \\
\hline Dostępność ulotek, formularzy i druków & 4,35 & 3,83 \\
\hline $\begin{array}{l}\text { Przystępny, zrozumiały język ulotek, druków } \\
\text { i formularzy }\end{array}$ & 4,35 & 3,86 \\
\hline
\end{tabular}

Źródło: opracowanie własne. 
Kolejne porównanie dotyczy wyglądu budynków i warunków panujących wewnątrz nich.

$\mathrm{Z}$ przedstawionego zestawienia wynika, że ponownie klienci lepiej postrzegają budynki urzędu niż pracownicy. Wiązać się to może $\mathrm{z}$ chęcią pracy w estetycznym i ładnym miejscu. Najbardziej pozytywne w odbiorze pracowników są godziny otwarcia wydziałów, co może być uzasadnione tym, że kończąc pracę po godzinie 15.30, sami poświęcą więcej czasu na życie rodzinne i własne potrzeby. Jednogłośnie najgorzej ocenione zarówno przez interesantów, jak i pracowników zostały miejsca parkingowe dostępne przed Urzędami oraz udogodnienia dla niepełnosprawnych. Jednomyślność w tych kwestiach wskazuje na to, że są to problemy, które należałoby rozwiązać w pierwszej kolejności, lecz jak już wcześniej wspomniałam, najczęściej nie pozwalają na to warunki techniczne budynków.

Ciekawe zjawisko można zauważyć, porównując częstotliwość odwiedzin urzędowej strony internetowej - uzyskane wartości są do siebie odwrotnie proporcjonalne.

Wykres 19. Porównanie odwiedzin strony internetowej

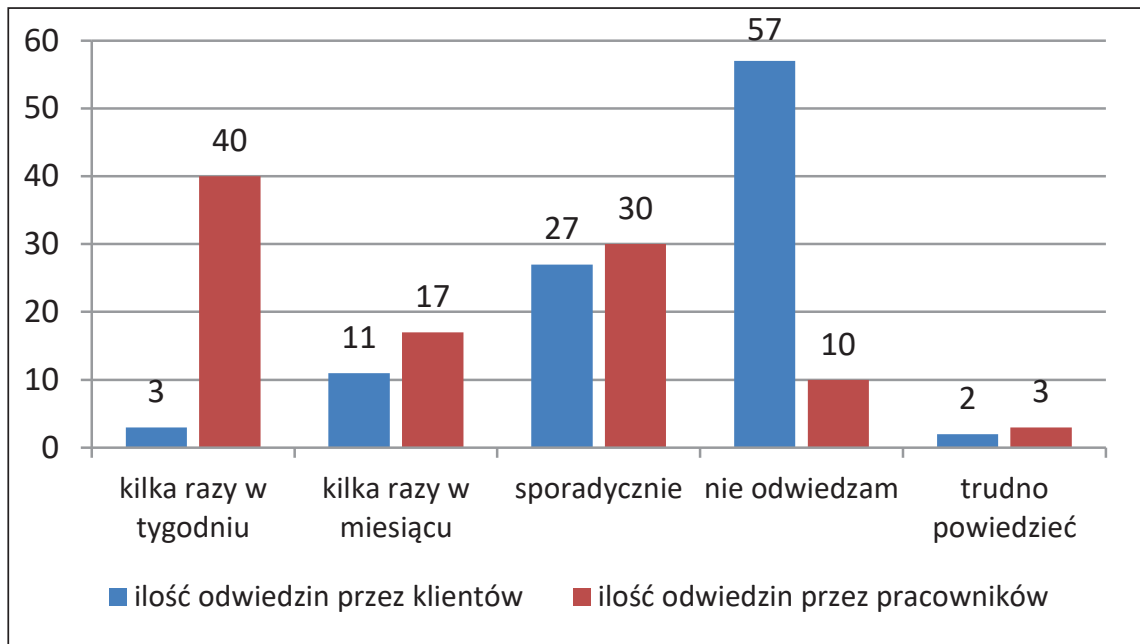

Źródło: opracowanie własne.

Zebrane odpowiedzi ukazują, że jedynie sporadyczne odwiedziny stron internetowych są na podobnych poziomach. Pracownicy wykorzystują urzędową stronę internetową znacznie częściej niż klienci. Można to tłumaczyć charakterem pracy, po części związanym z danymi, które się na niej znajdują, lecz pracownicy wykorzystują również to źródło do kontaktu z interesantami. Małe zainteresowanie klientów stroną świadczy o przekonaniu, że lepszy jest kontakt osobisty, który daje pewność zdobytych informacji, niż samoistne szukanie ich w sieci. 
Ostatnie porównanie dotyczy oceny strony internetowej przez pracowników i interesantów.

Tabela 3. Porównanie średniej oceny strony internetowej

\begin{tabular}{|l|c|c|}
\hline \multicolumn{1}{|c|}{ KATEGORIA ODPOWIEDZI } & KLIENCI & PRACOWNICY \\
\hline Wygląd, szata graficzna & 3,88 & 3,73 \\
\hline Możliwość znalezienia potrzebnych informacji & 3,82 & 3,5 \\
\hline Możliwość wyszukania pracowników/wydziałów & 3,64 & 3,73 \\
\hline Możliwość ściągania dokumentów i formularzy & 4,13 & 3,6 \\
\hline Aktualność zamieszczonych danych & 4,06 & 3,7 \\
\hline
\end{tabular}

Źródło: opracowanie własne.

Ukazane powyżej wartości jednoznacznie wskazują na to, że pracownicy bardziej negatywnie oceniają stronę internetową urzędu niż interesanci. Wydawać by się mogło, że praca z serwisem i przyzwyczajenie do niego spowodują odwrotne reakcje. Niskie oceny wystawiane przez pracowników mogą być spowodowane różnym stopniem zaawansowania potrzeb. Klienci mogą wyszukiwać podstawowe dane, potrzebne formularze, a pracownikom mogą być potrzebne dane bardziej szczegółowe, które często nie pojawiają się w serwisie. Negatywna ocena aktualności zamieszczanych danych najprawdopodobniej spowodowana jest tym, że pracownicy szybciej przekazują sobie informacje dotyczące Urzędu ustnie niż pojawiają się one w serwisie.

\section{Zakończenie}

Wyniki przeprowadzonych badań pokazały, że założenia zawarte w początkowych hipotezach nie mają odzwierciedlenia w rzeczywistości. Większa część odpowiedzi udzielanych przez interesantów i pracowników Urzędu Miasta Krakowa była podobna, a w wielu przypadkach wskazania klientów były przychylniejsze niż odpowiedzi pracowników Urzędu. Ocena przedstawiona przez interesantów była bardzo wysoka - 4,02 (w pięciostopniowej skali), a wartość wykazana przez pracowników wyniosła 3,79. Wydaje się to paradoksem, ponieważ pracownikom powinno bardziej zależeć na dobrym wizerunku ich pracodawcy niż klientom, ponieważ pracownicy tworzą to miejsce. Średnia ocena Urzędu wystawiona przez klientów i urzędników wyniosła 3,91. Jest to bardzo dobry wynik. Jedynymi problemami, na które zwróciły uwagę obie grupy ankietowanych, są brak udogodnień dla osób niepełnosprawnych oraz brak miejsc parkingowych dla interesantów. Poprawy wymaga kontakt telefoniczny (odbieranie telefonów przez pracowników), a ogólny wynik przeprowadzonego badania byłby z wyższy. Niezbędne wydaje się zdyscyplinowanie pracowników 
do odbierania telefonów poprzez monitoring nieodebranych rozmów oraz szkolenia pracowników w zakresie obsługi interesanta.

\section{Bibliografia}

Black S., Public relations, Warszawa 1999.

Comte A., Rozprawa o duchu filozofii pozytywnej, Warszawa 1973.

Filipek P., Public relations $w$ Polsce i na świecie, jej funkcja w zarzadzaniu przedsiębiorstwem (czyli skuteczne komunikowanie) [w:] P. Bielawski, Seminarium z zakresu Komunikacji Społecznej w Zarządzaniu dla kadry kierowniczej KGHM Polska Miedź SA, Świeradów, październik 1996-Szklarska Poręba, styczeń 1997.

Goban-Klas T., Public relations, czyli promocja reputacji, Warszawa 1999.

Kuśmierski S., Public relations $w$ procesie opiniotwórczym, Warszawa 2006.

Lazarsfeld P.F., „Kultura i Społeczeństwo” 1986, t. XXX, nr 3.

Maćkowska R., Znaczenie kreowania wizerunku samorzadu terytorialnego [w:] Public relations instytucji użyteczności publicznej, E. Hope (red.), Gdańsk 2005.

Noelle-Neumann E., Spirala milczenia, Warszawa 2001.

Rousseau J.-J., Umowa społeczna, Poznań 1920.

Skała M., Manipulacja odczarowana, Gliwice 2015.

Szymczak R., Mierzenie efektywności w PR: Trudne nie znaczy niemożliwe [w:] Sztuka public relations. $Z$ doświadczenia polskich praktyków, Warszawa 2011.

Streszczenie

Artykuł poświęcony jest wizerunkowi publicznemu Urzędu Miasta Krakowa. Badania przeprowadzone zostały wśród klientów i pracowników, a ich wyniki zostały ze sobą porównane i omówione.

Słowa kluczowe: administracja, Urząd Miasta Krakowa, public relations, wizerunek publiczny, Kraków.

\section{The Public Image of the Municipality of Cracow}

Abstract

The article focuses on the public image of the Municipality of Cracow. It compares and discusses the results of a survey was conducted amongst its clients and employees.

Keywords: administration, Municipality of Cracow, public relations, public image, Cracow 